\title{
Virus-like particles in Perkinsus atlanticus (Apicomplexa, Perkinsidae)
}

\author{
Carlos Azevedo
}

Department of Cell Biology, Institute of Biomedical Sciences, University of Oporto, Lg. A. Salazar no 2, P-4000 Porto, Portugal

\begin{abstract}
Virus-like particles (VLP) were observed in different phases of the in vitro zoosporulation of Perkinsus atlanticus (Apicomplexa, Perkinsidae) which parasitized the gill tissues of Ruditapes decussatus (Mollusca, Bivalvia). These VLP were represented by numerous electron-dense bodies (ca $125 \mathrm{~nm}$ diameter) not previously described in similar culture processes. The VLP were densely packed in a membrane-lined inclusion of isolated host-cell cytoplasm of parasitic origin. They were also found among prezoosporangia and zoosporangia of $P$. atlanticus, a species that causes recurrent mortalities in the clam $R$. decussatus. The ultrastructural organization of these VLP seems to represent a new and unclassified virus of $P$. atlanticus.
\end{abstract}

\section{INTRODUCTION}

The occurrence of viruses and virus-like particles (VLP) among eucaryotic algae, lower fungi and protozoan species was reported by Lemke (1976), who recorded an extensive list of eucaryotic algae in which viruses and VLP have been observed. In addition several reviews on algal viruses have been written (Sherman \& Brown 1978, Dodds 1979, Lauckner 1983).

The isolation and characterization of some viruses has also been described from several types of hosts (Dodds \& Cole 1980, Stanker et al. 1981, Van Etten et al. 1981, 1985, Martin \& Benson 1982, Schuster et al. $1986 \mathrm{a}, \mathrm{b})$.

This paper describes the presence of VLP infecting cultures of the apicomplexan protozoan Perkinsus atlanticus (Levine 1978), a new recently described species (Azevedo 1989).

\section{MATERIALS AND METHODS}

Several trophozoites of Perkinsus atlanticus (Azevedo 1989) isolated from gill tissues of Ruditapes decussatus, a clam of great commercial importance in Portugal, were prepared for zoosporulation in fluid thioglycollate medium according to a previously used technique (Chu \& Greene 1989), as modified by Azevedo (1989). After centrifugation, the pellet was fixed in $3 \%$ glutaraldehyde in $0.1 \mathrm{M}$ cacodylate buffer, at $\mathrm{pH} 7.8$ for $2 \mathrm{~h}$ at $4{ }^{\circ} \mathrm{C}$, washed for $2 \mathrm{~h}$ at $4{ }^{\circ} \mathrm{C}$ and postfixed in $2 \%$ osmium tetroxide in the same buffer and conditions (Azevedo 1989). The material was dehydrated through a graded series of ethanol solutions and embedded in Epon. Ultrathin sections were double stained with uranyl acetate and lead citrate and examined in a JEOL $100 \mathrm{CXII}$ TEM at $60 \mathrm{kV}$.

\section{RESULTS}

Among different developmental stages of Perkinsus atlanticus zoosporulation, some trophozoites were seen to be infected by numerous membrane-bound electrondense bodies. These bodies resembled VLP tightly packed in a membrane-lined inclusion in the trophozoite cytoplasm (Figs. 1 to 4). The VLP were regularly distributed in paracrystalline parallel arrays (Figs. 2 and 3) among the different cytoplasmic structures; these included mitochondria, lipid droplets, cisternae of reticulum, free ribosomes, and vacuoles of the trophozoites (Figs. 3 and 4). They had a density of 64 VLP $\mu \mathrm{m}^{-2}$ (Figs. 2 and 3). The periphery of the infected trophozoites showed a dense material that seemed to reinforce the plasmalemma (Figs. 3 and 4).

At high magnification, the VLP appeared different according to the plane of section. They were hexagonal and $\mathrm{ca} 125 \mathrm{~nm}$ in diameter. The internal matrix was 

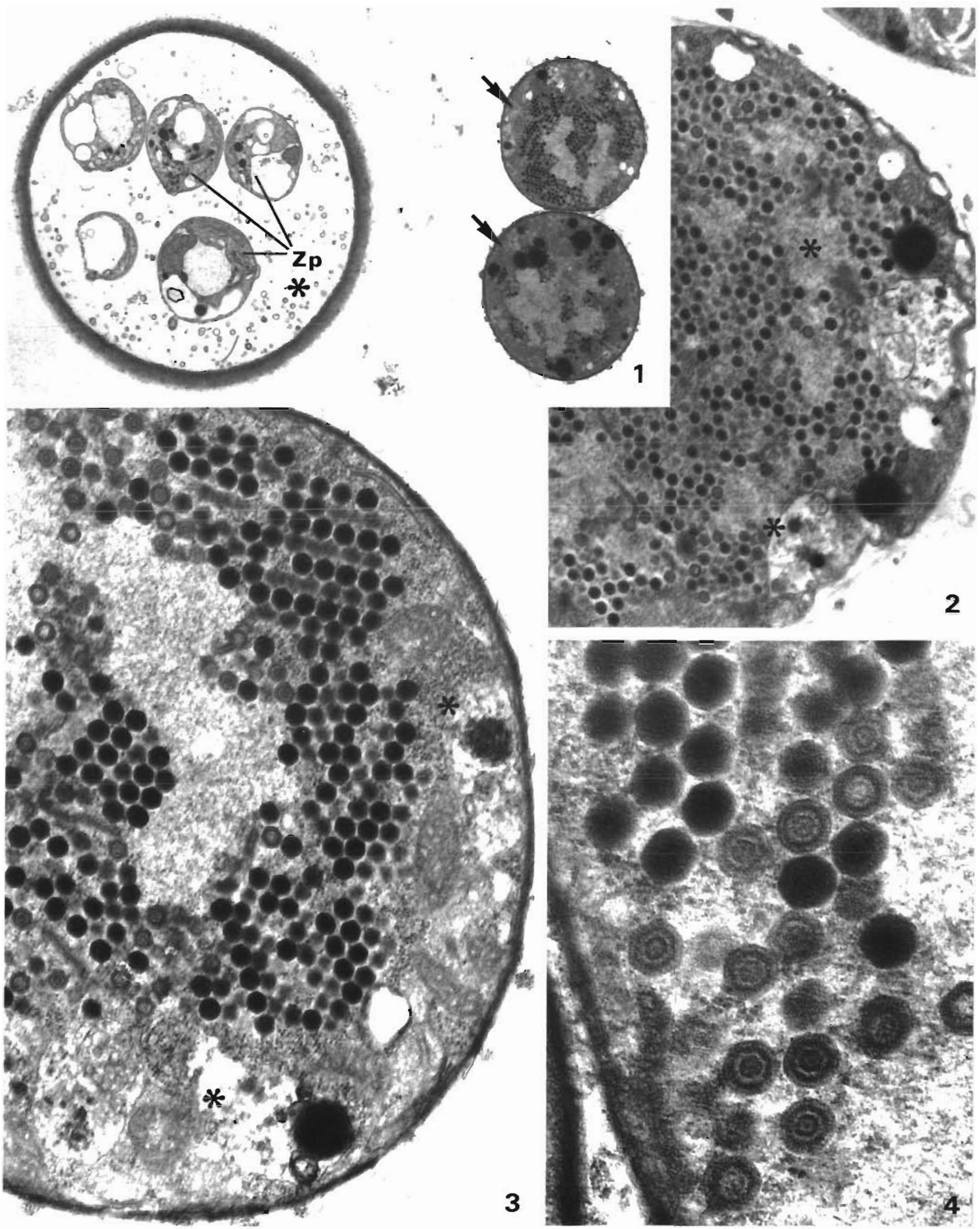

Figs. 1 to 4 Perkinsus atlanticus Virus-like partıcles (VLP) in the parasite $P$ atlanticus which infects the gill tissue of $R$ uditapes decussatus Fig. 1. Right two free host trophozoltes (arrows) containing several VLP; left: an isolated zoosporangium (*) of $P$. atlanticus showing some immature zoospores $(\mathrm{Zp}), \times 5800$ Fig. 2 . Two tree trophozoltes from Fig. 1 showing the VLP regularly distributed in the cytoplasm (*). Some signs of lysis are also visible: $\times 19000$. Fig 3 . Host cytoplasm (*) with lytic aspect containung numerous VLP; $\times 32000$. Fig 4 High magnification of a group of VLP sectioned at different levels; $\times 80000$ 
electron-dense and its internal organization was hardly visible (Fig. 4). In favorable sections it was possible to observe that the VLP contained a central spherical core measuring ca $50 \mathrm{~nm}$, surrounded by a circular and concentric layer situated between the central core and the external capsid (Fig. 4). Host cells containing VLP appeared degenerate, mainly at the periphery just beneath the plasmalemma. Some dense bodies, possibly lipid droplets, were scattered throughout the cytoplasm (Figs. 1 to 3 ). The nuclear membranes appeared to be ruptured or fragmented when the VLP were seen in the cytoplasm (Fig. 3).

\section{DISCUSSION}

The occurrence of VLP in the earliest phases of the in vitro zoosporulation of Perkinsus atlanticus is rare and an incidental finding noted during ultrastructural studies. The origin of these VLP is not clear, but they appear to be derived from host cells associated with high water-temperature during zoosporulation (Chu \& Greene 1989).

No evidence of the life cycle of these VLP was observed, but our specimens exhibit a similar hexagonal outline to previously published electron micrographs of VLP in different marine animal groups (Rungger et al. 1971, Farley et al. 1972, Comps \& Duthoit 1976, Buchanan \& Richards 1982). Some indication of a reduction in the final number of zoospores was found in the in vitro zoosporulation process when some trophozoites contained VLP. The presence of VLP caused disintegration of host cells and may also have interfered with zoospore multiplication when released into culture medium.

Similar polygonal VLP have been observed in eucaryotic algae (Lemke 1976, Dodds 1979, Dodds \& Cole 1980, Van Etten et al. 1981). However, the lack of the characterization of these VLP does not permit their classification.

This is the first record of the presence of VLP in the in vitro culture of zoosporulation in this apicomplexan protozoan. In future, attempts should be made to isolate, culture and further study the pathogenicity and transmissibility of these VLP and to determine their relationship if any with clam mortalities.

Acknowledgement. This work was partially supported by CME-INIC, JNICT, and DGQA.

Responsible Subject Editor: Professor O. Kinne, Oldendorf/ Luhe, F.R. Germany

\section{LITERATURE CITED}

Azevedo, C. (1989). Fine structure of Perkinsus atlanticus n. sp. (Apicomplexa, Perkinsea) parasite of the clam Ruditapes decussatus from Portugal. J. Parasit. 75: 627-635

Buchanan, J. S., Richards, R. H. (1982). Herpes-type virus diseases of marine organisms. Proc. R. Soc. Edinb. (Sect. B) 81. 151-168

Chu, F.-L. E., Greene, K. H. (1989). Effect of temperature and salinity on in vitro culture of the oyster pathogen, Perkinsus marinus (Apicomplexa, Perkinsea). J. Invertebr. Path 53: $260-268$

Comps, M., Duthoit, J.-L. (1976). Infection virale associée à la 'maladie des branchies' de l'huittre portugaise Crassostrea angulata Lmk. C.r. hebd. Séanc. Acad. Sci., Paris. 283: $1595-1596$

Dodds, J. A. (1979). Viruses of marine algae. Experimentia 35: $440-442$

Dodds, J. A., Cole, A. (1980). Microscopy and biology of Uronema gigas, a filamentous eucaryotic green alga, and its associated tailed virus-like particle. Virology 100: 156-165

Farley, C. A., Banfield, W. G., Kasnic, C. Jr, Foster, W. S. (1972). Oyster Herpes-type virus. Science 178: 759-760

Lauckner, G. (1983). Diseases of Mollusca: Bivalvia. In: Kinne, O. (ed.) Diseases of marine animals, vol. II. Biologische Anstalt Helgoland, Hamburg, p. 477-961

Lemke, P. A. (1976). Viruses of eucaryotic microorganisms. A. Rev. Microbiol. 30: 105-145

Levine, N. D. (1978). Perkinsus gen. n. and other new taxa in the protozoan phylum Apicomplexa. J. Parasit. 64: 549

Martin, E. L., Benson, R. L. (1982). Algal viruses, pathogenic bacteria and fungi: introduction and biobliography. In: Rosowski, J. R., Parker, B. C. (eds.) Selected papers in phycology. vol. Il. Phycological Society of America, Inc. New York, p. 793-798

Rungger, D., Rastelli, M., Braendle, E., Malsberger, R. G (1971). A viruslike particle associated with lesions in the muscles of Octopus vulgaris. J. Invertebr. Path. 17: 72-80

Schuster, A. M., Girton, L., Burbank, D. E., Van Etten, J. L (1986a). Infection of a Chlorella-like alga with the virus PBCV-1: transcriptional studies. Virology 148: 181-189

Schuster, A. M., Burbank, D. E., Meister, B., Skrdla, M. P., Meintz, R. H., Hattman, S., Swinton, D., Van Etten, J. L. (1986b). Characterization of viruses infecting a eukaryotic Chlorella-like green alga. Virology 150: 170-177

Sherman, L. A., Brown, R. M., Jr (1978). Cyanophages and viruses of eukaryotic algae. In: Frankel-Conrat, $\mathrm{H}$., Wagner, R. R. (eds.) Comprehensive virology, vol. 12. Plenum Press, New York, p. 145-234

Stanker, L. H., Hoffman, L. R., MacLeod, R. (1981). Isolation and partial characterization of a virus-like particle from a eukaryotic alga. Virology 114: 357-369

Van Etten, J. L., Meints, R. H., Burbank, D. E., Kuczmarski, D., Cuppels, D. A., Lane, L. C. (1981). Isolation and characterization of a virus from the intracellular green alga symbiotic with Hydra viridis. Virology 113: 704-711

Van Etten, J. L., Burbank, D. E., Schuster, A. M., Meints, R. H. (1985). Lytic viruses infecting a Chlorella-like alga. Virology 140: 135-143

Manuscript first received: November 7,1989

Revised version accepted: June 6, 1990 